\title{
Effects of spray-drying and storage on astaxanthin content of Haematococcus pluvialis biomass
}

\author{
Maria Filomena J. Raposo • Alcina M. M. B. Morais • \\ Rui M. S. C. Morais
}

Received: 14 September 2010/Accepted: 18 October 2011/Published online: 1 November 2011

(C) Springer Science+Business Media B.V. 2011

\begin{abstract}
The main objective of this study was to evaluate the stability of astaxanthin after drying and storage at different conditions during a 9-week period. Recovery of astaxanthin was evaluated by extracting pigments from the dried powders and analysing extracts by HPLC. The powders obtained were stored under different conditions of temperature and oxygen level and the effects on the degradation of astaxanthin were examined. Under the experimental conditions conducted in this study, the drying temperature that yielded the highest content of astaxanthin was $220^{\circ} \mathrm{C}$, as the inlet, and $120^{\circ} \mathrm{C}$, as the outlet temperature of the drying chamber. The best results were obtained for biomass dried at $180 / 110^{\circ} \mathrm{C}$ and stored at $-21^{\circ} \mathrm{C}$ under nitrogen, with astaxanthin degradation lower than $10 \%$ after 9 weeks of storage. A reasonable preservation of astaxanthin can be achieved by conditions $180 / 80^{\circ} \mathrm{C},-21^{\circ} \mathrm{C}$ nitrogen, $180 / 110^{\circ} \mathrm{C}, 21^{\circ} \mathrm{C}$ nitrogen, and $220 / 80^{\circ} \mathrm{C}, 21^{\circ} \mathrm{C}$ vacuum: the ratio of astaxanthin degradation is equal or inferior to $40 \%$. In order to prevent astaxanthin degradation of Haematococcus pluvialis biomass, it is recommended the storage of the spray dried carotenized cells $\left(180 / 110^{\circ} \mathrm{C}\right)$ under nitrogen and $-21^{\circ} \mathrm{C}$.
\end{abstract}

Keywords Haematococcus pluvialis · Carotenoids . Astaxanthin · Spray drying $\cdot$ Storage

M. F. J. Raposo - A. M. M. B. Morais · R. M. S. C. Morais ( $\square)$ $\mathrm{CBQF} /$ Escola Superior de Biotecnologia-Universidade Católica Portuguesa, Rua Dr. António Bernardino de Almeida, 4200-072 Porto, Portugal

e-mail: rmmorais@esb.ucp.pt

\section{Introduction}

Astaxanthin $\left(3,3^{\prime}\right.$-dihydroxy- $\beta, \beta$-carotene- $4,4^{\prime}$-dione $)$ is widely distributed in aquatic animals. It is the main pigment in salmonids, crustaceans, some higher plants and in the yeast Xanthophyllomyces dendrorhous (Phaffia rhodozyma). Astaxanthin is at least partly present in most plant and animal materials as esters of higher fatty acids. This is also the case of the unicellular microalga $H$. pluvialis, which is able to biosynthesise and accumulate astaxanthin in concentrations up to 5\% (more frequently $1-3 \%$ ) of its ash free dry weight. Approximately $90 \%$ of this astaxanthin exists in form of mono- and diesters (Harker et al. 1996; Lorenz and Cysewski 2000). For this reason, $H$. pluvialis is a good natural source of astaxanthin to be included in feeds for fish and crustaceans in aquaculture. On the other hand, as salmonids cannot synthesise carotenoids de novo, the reddish colour of their flesh depends mostly on dietary supplements, especially those containing carotenoids.

Several techniques were already tested in order to evaluate the effects on the recovery of astaxanthin from $H$. pluvialis (Mendes-Pinto et al. 2001). In this study, spray drying produced the highest carotenoid content biomass. Another study also showed that spray drying can be used without excessive degradation of carotenoids (Leach et al. 1998). Nevertheless, after obtaining the microalgae dried biomass, it has to be stored until used and/or incorporated in fish/crustacean feeds. There is scarce information published about this subject.

In this work, $H$. pluvialis encysted cells, rich in astaxanthin, were spray-dried at different temperatures and stored under different conditions. The pigment degradation of these powders was evaluated during a storage period of 9 weeks. 


\section{Materials and methods}

Cultures

Haematococcus pluvialis (34/7 strain of CCAP, Windermere, UK) cells were batch cultivated in Bold's Basal Medium (Nichols and Bold 1964) in glass flasks of $10 \mathrm{~L}$ in a chamber with control of light and temperature. Cultures were kept at constant temperature $\left(21^{\circ} \mathrm{C}\right)$ and light intensity ( $45 \mu \mathrm{mol}$ photon. $\mathrm{m}^{-2} \mathrm{~s}^{-1}$ ), and a photoperiod of $12 \mathrm{~h}$ light/12 h dark. Agitation of the cultures was performed by gently bubbling of filtered compressed air. When the stationary phase of growth was achieved, cultures were transferred to another chamber with constant temperature $\left(35^{\circ} \mathrm{C}\right)$ and continuous light $\left(80 \mu \mathrm{mol}\right.$ photon. $\left.\mathrm{m}^{-2} \mathrm{~s}^{-1}\right)$, to induce carotenogenesis of cells, for a 7-week period. Before spray drying, cells were harvested and centrifuged (10 $\mathrm{min}, 1,000 \mathrm{~g}$ ) to concentrate the biomass.

\section{Spray drying}

Carotenised cultures of $H$. pluvialis were spray dried using a Niro Atomiser Mobile Minor Unit. Characteristics and the ways to adjust temperatures are described elsewhere (Leach et al. 1998). Four drying experiments were accomplished; bottles used to collect the powders were always covered with aluminium foil in order to prevent major degradation of pigments. Drying inlet/outlet temperatures tested were $\left({ }^{\circ} \mathrm{C}\right)$ I-220/120; II-220/80; III-180110; IV-180/80. Experiments were carried out twice.

Determination of water content and ash free dry weight

For evaluation of the dry weight, a precise weighed amount of powder was dried overnight, at $105^{\circ} \mathrm{C}$, until constant weight was achieved. Determination of ashes was achieved after transferring the sample dried at $105^{\circ} \mathrm{C}$ to an oven at $550^{\circ} \mathrm{C}$ for $1 \mathrm{~h}$. All determinations were executed in triplicate. Dry weight and ashes were evaluated in the concentrated biomass (before drying) and immediately after each drying assay.

Water content and ash free dry weight (AFDW) were calculated.

Storage of the dried powders

The powder collected from each drying experiment was divided in aliquots of $100 \mathrm{mg}$ and introduced in amber glass vials of $20 \mathrm{ml}$ capacity. All flasks contained approximately the same quantity of powder to ensure equal headspace volume in all samples. These flasks were further grouped in four sets, each with the same number of vials. Storage conditions are indicated in Table 1.
Table 1 Storage conditions of the $H$. pluvialis dried powder

\begin{tabular}{lllll}
\hline Condition & $\mathrm{A}$ & $\mathrm{B}$ & $\mathrm{C}$ & $\mathrm{D}$ \\
\hline Storage condition & $\mathrm{N}_{2}$ & $\mathrm{~N}_{2}$ & Air & Vacuum \\
& $-21^{\circ} \mathrm{C}$ & $21^{\circ} \mathrm{C}$ & $-21^{\circ} \mathrm{C}$ & $21^{\circ} \mathrm{C}$ \\
\hline
\end{tabular}

For two of the sets (A and B), nitrogen gas (type C45, with a residual $\mathrm{O}_{2}$ concentration of $4 \mathrm{vpm}$ and a residual water of $3 \mathrm{vpm}$ ) was flushed into the glass vials for $1 \mathrm{~min}$, in order to guarantee the removal of air. Samples that were stored in normal air (C) were packed in similar glass flasks also with similar Teflon caps. A MULTIVAC Gastriovac machine (Multivac Sepp Haggenmüller KG) was used to create vacuum in one set of the flasks (D); conditions were set-up in order to obtain a vacuum level of 3 mbar. The gathering of samples for pigment analyses was made by picking up two flasks at random from each storing chamber every fortnight with the exception of the samples stored at $21^{\circ} \mathrm{C}$ under normal air (in this case a sample was taken every week). The total time of storage was 9 weeks.

Carotenoid extraction and analyses

Solvents used for extraction were ethanol and diethylether $(1: 1 \mathrm{v} / \mathrm{v})$, both from Merck. Complete extraction of carotenoids was performed on concentrated biomass $(1 \mathrm{ml})$ and on spray-dried samples (30 mg powder). Rupture of cell walls was achieved by adding glass beads of $2 \mathrm{~mm}$ diameter to the extraction tubes, and subjecting them to vortexing (Heidolph Reax 2000-1 min, speed 7), ultrasound (Bandelin Sonorex, 0.6A; $35 \mathrm{kHz}-15 \mathrm{~min}$ ) and centrifugation $(5 \mathrm{~min}$ at $1,000 \mathrm{~g}$ ). Extracts were filtered through a cotton wool filter to remove cell debris, and evaporated to dryness under a constant flow of oxygen-free nitrogen.

Sample extracts were redissolved in acetone (Merck) and the spectrum analysed between 400 and $700 \mathrm{~nm}$ using a UV-Vis 1601 Shimadzu spectrophotometer. The absorbance of solutions in the same solvent was registered at $476 \mathrm{~nm}$ to calculate astaxanthin concentration using an extinction coefficient of 2100.

Acetone extracts were injected in a Beckman Gold HPLC System unit equipped with a diode array detector for continuous monitoring of peaks. Carotenoids were separated by a Vydac 201TP54 reverse phase C18 $(5 \mu \mathrm{m})$ column $(0.46 \times 25 \mathrm{~cm})$ (The Separation Group, Hesperia) A solvent gradient of acetonitrile (UV gradient, Romil)water $(9: 1 \mathrm{v} / \mathrm{v})$ (solvent A) and ethyl acetate (Riedel-de Haën) (solvent B) was employed: $100 \%$ of solvent A at $0 \mathrm{~min}$ to $100 \%$ of solvent $\mathrm{B}$ at $30 \mathrm{~min}$, until $35 \mathrm{~min}$. Standard of astaxanthin (Sigma Chemicals) was also analysed for comparison of retention times. 
Statistical analysis

Statistical analysis was performed using Statistica 6.0 (StatSoft Inc.). Significance between means (one-way Anova) was assessed by the post-hoc Tukey's Honest Significant Difference (HSD) test. Values were considered significantly different at $P<0.05$.

\section{Results and discussion}

All drying experiments yielded dark red free flowing powders with different water contents $(P<0.05)$ (Table 2). However, no differences were detected among the ash free dry weight contents for the different experiments. The astaxanthin content was higher for drying experiments at $220^{\circ} \mathrm{C}$ than at $180^{\circ} \mathrm{C}(P<0.05)$ (Table 2$)$. Despite working with different temperatures and materials, Niamnuy et al. (2008) also observed that higher drying temperatures led to higher contents of astaxanthin.
Ratio of astaxanthin degradation represents the amount of astaxanthin lost along the time of storage divided by the initial astaxanthin concentration in the biomass (after drying). Ratio of astaxanthin degradation along the storage time was adjusted with a polynomial model of the 2nd order, as the expression

ratio of astaxanthin degradation $=a * t^{2}+b * t+c$,

where $t$ is the storage time (in weeks) and $a, b, c$ are the coefficients of the model (Table 3 ). However, in case IVA (Fig. 1), a linear model fitted better the data $\left(\mathrm{R}^{2}=0.99\right)$, being a simpler representation of the tendency, and in case IIIA (Fig. 1) no adjustment was possible as the degradation was detectable only after 6 weeks of storage. The $1 \mathrm{st}$ derivative of this model, given by $2 a^{*} t+b(\mathrm{~g} / \mathrm{kg}$ AFDW/ week $\left.{ }^{-1}\right)$, represents the rate of astaxanthin degradation. The absolute value of the 2 nd derivative of the model, given by $|2 a|$ (g/kg AFDW/week ${ }^{-2}$ ), represents the acceleration of the degradation suffered by the dried powders.
Table 2 Water content, ash free dry weight (AFDW) and astaxanthin content of the dried powders

\begin{tabular}{llclll}
\hline $\begin{array}{l}\text { Drying } \\
\text { condition }\end{array}$ & $\begin{array}{l}\text { Inlet } \\
\text { temperature } \\
\left({ }^{\circ} \mathrm{C}\right)\end{array}$ & $\begin{array}{l}\text { Outlet } \\
\text { temperature } \\
\left({ }^{\circ} \mathrm{C}\right)\end{array}$ & $\begin{array}{l}\text { Water } \\
\text { content } \\
(\%)\end{array}$ & $\begin{array}{l}\text { AFDW } \\
(\mathrm{g} / \mathrm{kg})\end{array}$ & $\begin{array}{l}\text { Astaxanthin } \\
\text { content } \\
(\mathrm{g} / \mathrm{kg} \mathrm{AFDW})\end{array}$ \\
\hline I & 220 & 120 & $9.3 \pm 1.0 \mathrm{~b}$ & $464 \pm 4 \mathrm{a}$ & $6.2 \pm 0.6 \mathrm{a}$ \\
II & 220 & 80 & $3.6 \pm 0.2 \mathrm{c}$ & $566 \pm 24 \mathrm{a}$ & $4.6 \pm 0.3 \mathrm{~b}$ \\
III & 180 & 110 & $11.4 \pm 2.0 \mathrm{ab}$ & $612 \pm 14 \mathrm{a}$ & $3.3 \pm 0.4 \mathrm{c}$ \\
IV & 180 & 80 & $14.0 \pm 3.0 \mathrm{a}$ & $604 \pm 3.5 \mathrm{a}$ & $3.5 \pm 0.2 \mathrm{c}$ \\
\hline
\end{tabular}

Table 3 Curves of tendency for the ratio of astaxanthin degradation $\left(a t^{2}+b t+c\right)$, rates of astaxanthin degradation $(2 a t+b)$ and constants for the acceleration of degradation ( $2 a)$, for different conditions of storage of powders, obtained with different spray drying temperatures

\begin{tabular}{|c|c|c|c|c|}
\hline $\begin{array}{l}\text { Storage } \\
\text { condition }\end{array}$ & $\begin{array}{l}\text { Curve of } \\
\text { tendency }\end{array}$ & $\mathrm{R}^{2}$ & $\begin{array}{l}\text { Rate of degradation } \\
\text { (g/kgAFDW/week) }\end{array}$ & $\begin{array}{l}\text { Acceleration of degradation } \\
\left(\mathrm{g} / \mathrm{kgAFDW} \text { week }^{2}\right)\end{array}$ \\
\hline IA & $-0.0025 t^{2}+0.079 t-0.0269$ & 0.94 & $-0.005 t+0.0789$ & 0.005 \\
\hline IIA & $0.0035 \mathrm{t}^{2}+0.022 \mathrm{t}+0.0224$ & 0.98 & $0.007 t+0.022$ & 0.007 \\
\hline IIIA & - & - & - & - \\
\hline IVA & $0.0396 t+0.0022$ & 0.99 & - & 0.000 \\
\hline IB & $-0.0085 \mathrm{t}^{2}+0.1272+0.02$ & 0.98 & $-0.017 \mathrm{t}+0.1272$ & 0.017 \\
\hline IIB & $-0.006 t^{2}+0.1141 t-0.0084$ & 0.996 & $-0.012 \mathrm{t}+0.1141$ & 0.012 \\
\hline IIIB & $-0.0045 \mathrm{t}^{2}+0.0847 \mathrm{t}-0.0019$ & 0.999 & $-0.009 t+0.0847$ & 0.009 \\
\hline IVB & $-0.0065 \mathrm{t}^{2}+0.1415 \mathrm{t}+0.0396$ & 0.96 & $-0.013 t+0.1415$ & 0.013 \\
\hline IC & $-0.004 \mathrm{t}^{2}+0.1168 \mathrm{t}+0.0246$ & 0.91 & $-0.008 \mathrm{t}+0.1168$ & 0.008 \\
\hline IIC & $-0.0055 \mathrm{t}^{2}+0.1123 \mathrm{t}+0.0131$ & 0.97 & $-0.011 \mathrm{t}+0.1123$ & 0.011 \\
\hline IIIC & $0.006 t^{2}+0.0648 t-0.0367$ & 0.96 & $0.012 t+0.0648$ & 0.012 \\
\hline IVC & $-0.013 t^{2}+0.1985 t-0.0098$ & 0.99 & $-0.026 \mathrm{t}+0.1985$ & 0.026 \\
\hline ID & $-0.003 t^{2}+0.1229 t+0.0043$ & 0.998 & $-0.006 t+0.1229$ & 0.006 \\
\hline IID & $-0.006 \mathrm{t}^{2}+0.0949 \mathrm{t}-0.0131$ & 0.93 & $-0.012 t+0.0949$ & 0.012 \\
\hline IIID & $-0.004 \mathrm{t}^{2}+0.0838 \mathrm{t}+0.0096$ & 0.98 & $-0.008 t+0.0838$ & 0.008 \\
\hline IVD & $0.0005 t^{2}+0.082 t+0.017$ & 0.96 & $-0.001 \mathrm{t}+0.082$ & 0.001 \\
\hline
\end{tabular}


Fig. 1 Astaxanthin degradation in the biomass dried at temperatures of $220 / 120^{\circ} \mathrm{C}$ (I, diamonds), $220 / 80^{\circ} \mathrm{C}$ (II, squares), $180 / 110^{\circ} \mathrm{C}$ (IV, crosses) and stored under: A nitrogen and $-21^{\circ} \mathrm{C}$, B nitrogen and $21^{\circ} \mathrm{C}, \mathbf{C}$ normal air and $21^{\circ} \mathrm{C}, \mathbf{D}$ vacuum and $21^{\circ} \mathrm{C}$. Lines represent the tendency of astaxanthin degradation (III, triangles) and $180 / 80^{\circ} \mathrm{C}$
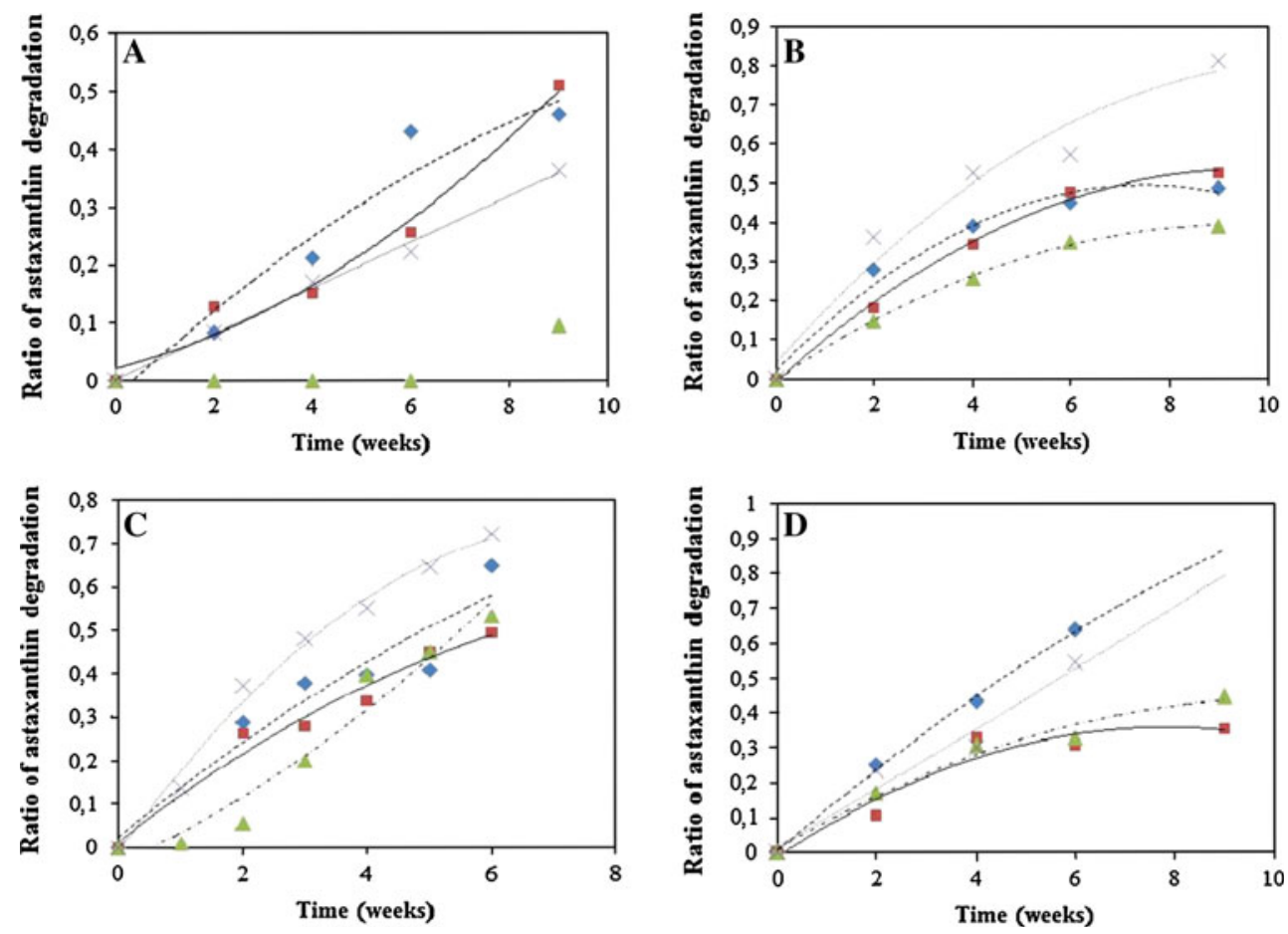

Table 4 Constants for the acceleration of astaxanthin degradation with time $\left(\right.$ week $^{-2}$ )

* Degradation was only detectable after 6 weeks of storage

\begin{tabular}{|c|c|c|c|c|c|}
\hline & \multicolumn{4}{|c|}{ Drying temperatures (inlet/outlet) } \\
\hline \multicolumn{2}{|c|}{ Storage condition } & \multirow{2}{*}{$\begin{array}{l}220 / 120^{\circ} \mathrm{C}(\mathrm{I}) \\
0.005\end{array}$} & \multirow{2}{*}{$\begin{array}{l}220 / 80^{\circ} \mathrm{C}(\mathrm{II}) \\
0.007\end{array}$} & \multirow{2}{*}{$\begin{array}{l}180 / 110^{\circ} \mathrm{C}(\mathrm{III}) \\
*\end{array}$} & \multirow{2}{*}{$\begin{array}{l}180 / 80^{\circ} \mathrm{C}(\mathrm{IV}) \\
0.000\end{array}$} \\
\hline $\mathrm{A}-21^{\circ} \mathrm{C}$ & Nitrogen & & & & \\
\hline B $21^{\circ} \mathrm{C}$ & Nitrogen & 0.017 & 0.012 & 0.009 & 0.013 \\
\hline $\mathrm{C} 21^{\circ} \mathrm{C}$ & Air & 0.008 & 0.011 & 0.012 & 0.026 \\
\hline D $21^{\circ} \mathrm{C}$ & Vacuum & 0.006 & 0.012 & 0.008 & 0.001 \\
\hline
\end{tabular}

The acceleration of the astaxanthin degradation is a convenient indicator of the best storage conditions of the biomass, for the 16 different situations studied.

As it was expected, results of the acceleration of astaxanthin degradation (Table 3) show that, at freezing temperatures $\left(-21^{\circ} \mathrm{C}\right)$ and under a nitrogen atmosphere (storage condition A), the degradation of astaxanthin is very slow (Fig. 1).

Figure 1A represents the pigment degradation of the dried biomass stored under nitrogen and $-21^{\circ} \mathrm{C}$. Stored under this condition, cells dried with an inlet temperature of $180^{\circ} \mathrm{C}$ and an outlet temperature of $110^{\circ} \mathrm{C}$, are remarkably more stable than the other powders: astaxanthin degradation was $<3 \%$, even after 6 weeks of storage (Table 4 and Fig. 1). Powders with lower water content (conditions I and II, Tables 2 and 4) presented a faster degradation than the ones with higher water content (conditions III and IV). Perhaps the wet character of the III and IV powders could somehow prevent the degradation under these conditions (Table 4).
When comparing the results of the astaxanthin degradation for the powders stored under $-21^{\circ} \mathrm{C}$ (A) and $21^{\circ} \mathrm{C}$ (B), both under nitrogen, the effect of temperature in the oxidation process is evident: the degradation is higher at $21^{\circ} \mathrm{C}$. After a 9-week period of storage under $21^{\circ} \mathrm{C}$, degradation of astaxanthin varied between 30 and $80 \%$ (Table 4 and Fig. 1B). As it happened for the condition A, acceleration of astaxanthin degradation was lower for powders with an intermediate water content (condition IIIB, Table 4). This observation is in agreement with the models available in the literature for $\beta$-carotene degradation (Lorenz and Cysewski 2000; Tanaka et al. 1994; Foss et al. 1984; Torrisen 1989). As there is some lack of references for astaxanthin stability in dried systems, $\beta$-carotene models seem to be the only ones available for comparison.

Although observation of the powders at the microscope showed that the majority of Haematococcus cells resisted the drying process, acting as a natural protector of their pigments, this characteristic was not sufficient when the 
powders were stored under $21^{\circ} \mathrm{C}$ and normal air (Fig. 1C). In this case, both temperature and oxygen contributed to the degradation of astaxanthin, which was always higher than $40 \%$ after 6 weeks of storage, with the highest acceleration observed for condition IVC (Table 3).

Except for the value obtained for condition IID (Table 4), whose constant for the acceleration of astaxanthin degradation was not much different from condition IIC, degradation of pigments were always lower for samples stored under nitrogen (D) than for those stored under normal air (C). These results are supported by Niamnuy et al. (2008), who also observed, despite the different temperatures they worked with, that degradation of pigments was lower under nitrogen than under normal air.

Besides the best results obtained for biomass dried at $180 / 110^{\circ} \mathrm{C}$ and stored at $-21^{\circ} \mathrm{C}$ under nitrogen (condition IIIA), a reasonable preservation of astaxanthin can be achieved by conditions IVA $\left(180 / 80^{\circ} \mathrm{C},-21^{\circ} \mathrm{C}\right.$ nitrogen), IIIB $\left(180 / 110^{\circ} \mathrm{C}, 21^{\circ} \mathrm{C}\right.$ nitrogen $)$, and IID $\left(220 / 80^{\circ} \mathrm{C}, 21^{\circ} \mathrm{C}\right.$ vacuum): the ratio of astaxanthin degradation is equal or inferior to $40 \%$ at the end of 9 weeks of storage.

\section{Conclusion}

In order to prevent astaxanthin degradation of Haematococcus pluvialis biomass, it is recommended the storage of the spray dried carotenized cells $\left(180 / 110^{\circ} \mathrm{C}\right)$ under nitrogen and $-21^{\circ} \mathrm{C}$. Nevertheless, other conditions of storage can also be used to prevent major astaxanthin degradation, such as vacuum at $21^{\circ} \mathrm{C}$.

\section{References}

Foss P, Storebakken T, Schiedt KM, Liaaen-Jensen S, Austreng E, Streiff K (1984) Carotenoids diets for salmonids: I. Pigmentation of rainbow trout with individual optical isomers of astaxanthin in comparison with canthaxanthin. Aquaculture 65:293-305

Harker M, Tsavalos AJ, Young AJ (1996) Autotrophic growth and carotenoid production of Haematococcus pluvialis in a 30 litre air-lift photobioreactor. J Ferment Bioeng 82:113-118

Leach GC, Oliveira G, Morais R (1998) Spray-drying of Dunaliella salina to produce a $\beta$-carotene rich powder. $\mathrm{J}$ Ind Microbiol Biotechnol 20:82-85

Lorenz RT, Cysewski GR (2000) Commercial potential for Haematococcus microalgae as a natural source of astaxanthin. Trends Biotechnol 18:160-167

Mendes-Pinto MM, de Raposo MF, Bowen J, Young AJ, Morais R (2001) Evaluation of different cell disruption processes on encysted cells os Haematococcus pluvialis: effects on astaxanthin recovery and implications for bio-availability. J Appl Phycol 13:19-24

Niamnuy C, Devahastin S, Soponronnarit S, Raghavan GSV (2008) Kinetics of astaxanthin degradation and colour changes of dried shrimp during storage. J Food Eng 87:591-600

Nichols HW, Bold HC (1964) Trichsarcina polymorpha gen. et nov. J Phycol 1:34-38

Tanaka T, Morishita Y, Suzui M, Kojima T, Okumura A, Mori A (1994) Chemoprevention of mouse urinary bladder carcinogenesis by naturally occurring carotenoid astaxanthin. Carcinogenesis 15:15-19

Torrisen O (1989) Pigmentation and salmonids: interactions of astaxanthin and canthaxanthin on pigment deposition in rainbow trout. Aquaculture 79:363-374 